Е. А. Убеева, С. М. Николаев, И. П. Убеева, Д. Н. Оленников, А. О. Занданов. Определение противовирусных свойств комплексного фитоэкстракта

Научная статья

УДК 615.32

DOI: $10.18101 / 2306-1995-2021-2-3-8$

\title{
ОПРЕДЕЛЕНИЕ ПРОТИВОВИРУСНЫХ СВОЙСТВ КОМПЛЕКСНОГО ФИТОЭКСТРАКТА
}

\author{
(C) Убеева Елена Александровна \\ кандидат медицинских наук, старший преподаватель, \\ Бурятский государственный университет имени Доржи Банзарова \\ Россия, 670000, г. Улан-Удэ, ул. Октябрьская, 36а \\ ubeeva.ip@mail.ru
}

\section{(C) Николаев Сергей Матвеевич}

доктор медицинских наук, профессор, Бурятский государственный университет имени Доржи Банзарова главный научный сотрудник, Институт общей и экспериментальной биологии СО РАН Россия, 670047, г. Улан-Удэ, ул. Сахьяновой, 6 tatur75@mail.ru

\section{(C) Убеева Ираида Поликарповна}

доктор медицинских наук, профессор, заведующая кафедрой инфекционных болезней, Бурятский государственный университет имени Доржи Банзарова Россия, 670000, г. Улан-Удэ, ул. Октябрьская, 36а ubeeva.ip@mail.ru

\section{(с) Оленников Даниил Николаевич}

доктор биологических наук, старший научный сотрудник,

Институт общей и экспериментальной биологии Сибирского отделения РАН Россия, 670013, г. Улан-Удэ, ул. Сахьяновой, 6

olennikovdn@mail.ru

\section{(C) Занданов Александр Октябрьевич}

кандидат медицинских наук, доцент, директор Медицинского института, Бурятский государственный университет имени Доржи Банзарова Россия, 670000, г. Улан-Удэ, ул. Октябрьская, 36а

Аннотация. Определялось противовирусное действие нового сухого фитоэкстракта, состоящего из лекарственных растений Hypecoum erectum L.; Hedysarum alpinum L.; Glycyrrhiza uralensis Fisch.; Calendula officinalis L.; Scutellaria baicalensis Georgi., обладающего гепатопротективным действием. В культуре клеток in vitro выявлено отсутствие цитопатогенного действия (ЦПД) сухого экстракта и его компонентов. Изучение цитотоксических и противовирусных свойств экстракта «Гипелив» и его компонентов с помощью микрометода позволило установить наличие значительного противовирусного потенциала указанных веществ, причем наибольшая способность подавления цитопатогенного действия вируса выявлена у экстрактов солодки и календулы и изучаемого экстракта.

Ключевые слова: фитополиэкстракт, гепатопротективное, противовирусное действие, сухой экстракт, компоненты. 


\section{Для цитирования}

Определение противовирусных свойств комплексного фитоэкстракта / Е. А. Убеева, С. М. Николаев, И. П. Убеева и др. // Вестник Бурятского государственного университета. Медицина и фармация. 2021. № 2. С. 3-8.

\section{Введение}

Необходимость определения противовирусных свойств гепатопротективных препаратов определяется широкой распространенностью вирусных инфекций $[1,2]$. Повреждение печени развивается при вирусных гепатитах A, B, C, D, E и F, воздействии цитомегаловирусов, вирусов Эпштейна - Барр, аденовирусов и др. Нередко развиваются затяжные и хронические формы с тяжелыми последствиями, особенно для групп риска. Авторы отмечают ограниченное количество этиотропных противовирусных препаратов при подавляющем большинстве инфекций, что определяет актуальность поиска средств, сочетающих гепатопротективные свойства и противовирусный эффект. Комплексный фитоэкстракт «Гипелив» продемонстрировал отчетливое гепатопротективное действие в экспериментальных условиях, способность оказывать антиоксидантное, мембраностабилизирующее действие, снижать выраженность основных патогенетических синдромов повреждения печени [3].

Цель работы заключалась в определении противовирусных свойств комплексного фитосредства «Гипелив», обладающего гепатопротективным действием, in vitro в культуре клеток.

Meтоды. Определение противовирусного действия комплексного экстракта проводили с помощью микрометода в культуре клеток НЕР-2 эпидермоидной карциномы гортани человека, культивируемой в виде монослоя (ООО «БиолоТ» РФ, Санкт-Петербург) [2]. Культуру клеток инкубировали в пластиковых панелях с 96 лунками с плоским дном (КНР) с добавлением по 0,1 мл поддерживающей питательной среды Игла MEM c L-глютамином (OOO «БиолоТ» РФ, Санкт-Петербург).

Для выявления возможного цитопатогенного воздействия исследуемого экстракта сухого на культуру тканей определяли степень деструкции клеточного монослоя при добавлении в поддерживающую питательную среду «Гипелива» и его компонентов. Содержание культуры клеток осуществлялось в течение 48-72 часов при $36{ }^{\circ} \mathrm{C}$ и $5 \% \mathrm{CO}^{2}$, после чего определяли степень деструкции клеточного монослоя при помощи микроскопирования.

Оценка противовирусных свойств экстракта «Гипелив» и его компонентов осуществлялась на основе микрометода при использовании энтеровирусов с учетом ЦПД. Вначале проводилась предварительная обработка 24-часовой культуры клеток, выращенной в 96 луночных пластиковых панелях, разными концентрациями растворенного «Гипелива» и его компонентов, начиная с концентрации 900 мкг/мл за сутки до заражения вируссодержащей жидкостью. Необходимость предварительного внесения исследуемого экстракта и его компонентов в культуру за 24 часа до инфицирования вирусом связана с тем, что развитие максимального протективного эффекта указанных веществ наступает не ранее чем через 10 ч после внесения.

В дальнейшем при внесении вируссодержащей жидкости к культуре клеток, содержащей исследуемые экстракты в данной концентрации, через 48-72 часа 
Е. А. Убеева, С. М. Николаев, И. П. Убеева, Д. Н. Оленников, А. О. Занданов. Определение противовирусных свойств комплексного фитоэкстракта

(сроки максимального накопления вируса) культуру микроскопировали для определения противовирусной активности по ЦПД.

\section{Результаты и их обсуждение}

При выявлении цитопатогенного действия «Гипелива» и его компонентов на культуру клеток при добавлении в питательную поддерживающую среду исследуемого сухого экстракта и его компонентов в дозе 900 мкг/мл установлено полное отсутствие ЦПД.

Определение противовирусного действия изучаемого экстракта проводили с помощью микрометода в культуре клеток НЕР-2 эпидермоидной карциномы гортани человека. Через 48 часов после внесения вируссодержащей жидкости наблюдение и микроскопирование позволили отметить уменьшение цитопатогенного действия вируса (ЦПД) при добавлении в питательную поддерживающую среду «Гипелива» в дозе 900 мкг/мл на 40\%. Добавление сухого экстракта гипекоума прямого и копеечника альпийского сопровождалось уменьшением ЦПД на 10\%. При внесении в питательную среду сухих экстрактов календулы лекарственной и солодки уральской и «Гипелива» наблюдалось уменьшение ЦПД на 50\%, «Гипелива» - на 62\% по сравнению с контролем, что свидетельствует об отчетливой антивирусной активности данной концентрации. Через 72 часа после внесения вируссодержащей жидкости отмечалось выраженное ЦПД на культуру клеток (табл. 1).

Таблицьа 1

Противовирусная активность и цитопатогенное действие экстракта сухого «Гипелив» и его компонентов в концентрации 900 мкг/мл на культуре клеток

\begin{tabular}{|l|c|c|}
\hline \multirow{2}{*}{$\begin{array}{l}\text { Культура клеток } \\
\text { исследуемый экстракт сухой } \\
+ \text { вируссодержащая жидкость }\end{array}$} & \multicolumn{2}{|c|}{ ЦПД } \\
\cline { 2 - 3 } & \multicolumn{2}{|c|}{ Сроки наблюдения } \\
\cline { 2 - 3 } & 48 ч & 72 ч \\
\hline Шлемник байкальский & $100 \%$ & $100 \%$ \\
\hline Гипекоум прямой & $90 \%$ & $100 \%$ \\
\hline Календула лекарственная & $50 \%$ & $100 \%$ \\
\hline Солодка уральская & $50 \%$ & $100 \%$ \\
\hline Копеечник альпийский & $90 \%$ & $100 \%$ \\
\hline Экстракт сухой «Гипелив» & $38 \%$ & \\
\hline
\end{tabular}

На основании полученных данных установлено, что 50\%-ная ингибирующая концентрация экстрактов календулы лекарственной, солодки уральской составляет 900 мкг/мл, при этом репродукция вируса снижалась вдвое через 48 часов, а при введении «Гипелива» в той же концентрации - на 62\% (табл. 1).

Для установления диапазона противовирусной активности «Гипелива» и его составляющих опытным путем в зависимости от токсичности на культуру клеток с постепенным увеличением концентрации, с кратностью разведения $1: 2$, начиная с концентрации 900 мкг/мл, подбирали концентрацию с максимальной антивирусной активностью. Постепенно увеличивали концентрацию сухих экстрактов от 1000 мкг/мл до 10 мг/мл, 20 мг/мл и выше. Таким образом, был определен оптимальный диапазон противовирусной активности «Гипелива» и его компонентов в пределах от 20 до 40 мг/мл. 
При определении ЦПД на культуру клеток экстракта сухого и его компонентов в концентрации 20 мг/мл выявлено, что введение «Гипелива» и солодки уральской практически не приводило к гибели культуры клеток (табл. 2). При введении в культуру клеток сухих экстрактов гипекоума прямого, календулы лекарственной и «Гипелива» отмечали ЦПД в пределах $10 \%$, что свидетельствовало о слабом цитопатическом эффекте. Введение экстракта шлемника байкальского и гипекоума прямого оказывало более значительное ЦПД (до 30\%), выраженную токсичность демонстрировал сухой экстракт копеечника альпийского и гипекоума прямого.

Через 48-72 часа после добавления вируссодержащей жидкости на фоне введения «Гипелива» и компонентов в концентрации 20 мг/мл выявлено значительное уменьшение ЦПД при введении экстракта солодки уральской, календулы лекарственной и «Гипелива». В первые 24 часа после инфицирования вирус в культуре клеток накапливался в незначительных концентрациях, не вызывая выраженной деструкции клеток. Через 48 ч после инфицирования монослоя клеток эффективность подавления ЦПД при добавлении экстракта солодки и календулы составила $73 \%$, «Гипелива» - 81\%. Через 72 часа при использовании экстракта солодки и календулы лекарственной подавление цитопатической активности вируса в дальнейшем возрастало и достигло 50\%, при введении «Гипелива» - $40 \%$.

Таблииа 2

Противовирусная активность и цитопатогенное действие сухого экстракта «Гипелив» и его компонентов в концентрации 20 мг/мл

\begin{tabular}{|l|c|c|c|}
\hline \multirow{2}{*}{ Экстракты сухие } & \multicolumn{3}{|c|}{ ЦПД } \\
\cline { 2 - 4 } & $\begin{array}{c}\text { Культура клеток } \\
\text { + сухие } \\
\text { экстракты }\end{array}$ & \multicolumn{2}{|c|}{$\begin{array}{c}\text { Культура клеток } \\
\text { + сухие экстракты } \\
\text { + вируссодержащая жидкость }\end{array}$} \\
\hline Шлемник байкальский, & $30 \%$ & Срок 48 ч & Срок 72 ч \\
\hline Гипекоум прямой & $30 \%$ & $100 \%$ & $100 \%$ \\
\hline Календула лекарственная & $10 \%$ & $90 \%$ & $100 \%$ \\
\hline Солодка уральская & $5 \%$ & $27 \%$ & $50 \%$ \\
\hline Копеечник альпийский & $50 \%$ & $100 \%$ & $50 \%$ \\
\hline Экстракт сухой «Гипелив» & $9 \%$ & $19 \%$ & $100 \%$ \\
\hline
\end{tabular}

Следовательно, одновременное изучение цитотоксических и противовирусных свойств экстракта «Гипелив» и его компонентов позволило установить наличие противовирусного потенциала, причем наибольшая способность подавления ЦПД вируса выявлена у экстрактов солодки, календулы и изучаемого экстракта.

Данные о влиянии «Гипелива» и его компонентов на культуру клеток в концентрации 40 мг/мл позволили отнести его к малотоксичным соединениям, ЦПД не превышал 10\% (табл. 3). При добавлении вируссодержащей жидкости через 48 часов ЦПД составляло 90\%. 
Е. А. Убеева, С. М. Николаев, И. П. Убеева, Д. Н. Оленников, А. О. Занданов. Определение противовирусных свойств комплексного фитоэкстракта

Таблий 3

Противовирусная активность комплексного экстракта и его компонентов в концентрации 40 мг/мл

\begin{tabular}{|l|c|c|c|}
\hline \multirow{2}{*}{ Сухие экстракты } & \multicolumn{3}{|c|}{ ЦПД } \\
\cline { 2 - 4 } & $\begin{array}{c}\text { Культура клеток } \\
\text { + сухие } \\
\text { экстракты }\end{array}$ & \multicolumn{2}{|c|}{$\begin{array}{c}\text { Культура клеток } \\
\text { + сухие экстракты } \\
\text { вируссодержащая жидкость }\end{array}$} \\
\cline { 2 - 4 } & & 48 ч & 72 ч \\
\hline Шлемник байкальский & $70 \%$ & $100 \%$ & $100 \%$ \\
\hline Гипекоум прямой & $50 \%$ & $100 \%$ & $100 \%$ \\
\hline Календула лекарственная & $20 \%$ & $100 \%$ & $100 \%$ \\
\hline Солодка уральская & $20 \%$ & $100 \%$ & $100 \%$ \\
\hline Копеечник альпийский & $60 \%$ & $100 \%$ & $100 \%$ \\
\hline Экстракт сухой «Гипелив» & $20 \%$ & $90 \%$ & $100 \%$ \\
\hline
\end{tabular}

На основании полученных данных установлено, что 50\%-ная ингибирующая концентрация экстрактов календулы лекарственной и солодки уральской составляет 900 мкг/мл, при этом репродукция вируса снижалась вдвое. При использовании экстракта солодки в концентрации 20 мкг/мл в первые 24 ч после инфицирования вирус в культуре клеток накапливался в незначительных концентрациях, не вызывая значительной деструкции клеток. Через 48 ч после инфицирования монослоя клеток эффективность подавления вируса при добавлении экстракта солодки и календулы лекарственной составила $27 \%$.

Таким образом, изучение цитотоксических и противовирусных свойств экстракта «Гипелив» и его компонентов позволило установить наличие значительного противовирусного потенциала указанных веществ, причем наибольшая способность подавления ЦПД вируса выявлена у экстрактов солодки и календулы и изучаемого экстракта.

Литература

1. Инфекционные болезни: национальное руководство / под редакцией Н. Д. Ющука, Ю. Я. Венгерова. Москва: ГЭОТАР - Медиа, 2019. 11054 с. (Серия «Национальные руководства»). Текст: непосредственный.

2. Ершов Ф. И., Тазулахова Э. Б., Наровлянский А. Н. Методические рекомендации по доклиническому изучению специфической противовирусной активности лекарственных средств // Руководство по проведению доклинических исследований лекарственных средств. Москва: Гриф и К, 2012. Ч. І. С. 525-549. Текст: непосредственный.

3. Экспериментальная фитокоррекция острого D-га-лактозаминового гепатита у белых крыс / Е. А. Убеева, Я. Г. Разуваева, Д. Н. Оленников [и др.] // Якутский медицинский журнал. 2018. № 4. С. 33-36. Текст: непосредственный.

Статья поступила в редакцию 29.10.2021; одобрена после рецензирования 25.11.2021; принята к публикации 22.12.2021. 


\section{ANTIVIRAL PROPERTIES OF THE MIXED PLANT EXTRACT}

Elena A. Ubeeva

Cand. Sci. (Medicine), Senior Lecturer,

Dorzhi Banzarov Buryat State University

36a Oktyabrskaya St., Ulan-Ude 670000, Russia

ubeeva.ip@mail.ru

Sergey M. Nikolaev

Dr. Sci. (Medicine), Prof.,

Dorzhi Banzarov Buryat State University

36a Oktyabrskaya St., Ulan-Ude 670002, Russia

Chief Researcher,

Institute of General and Experimental Biology SB RAS,

6 Sakhynovoy St., Ulan-Ude 670047, Russia

smnikolaev@mail.ru

Iraida P. Ubeeva

Dr. Sci. (Medicine), Prof.,

Head of Infectious Diseases Department,

Dorzhi Banzarov Buryat State University

36a Oktyabrskaya St., Ulan-Ude 670000, Russia

ubeeva.ip@mail.ru

\section{Daniil N. Olennikov}

Dr. Sci. (Biol.), Senior Researcher,

Institute of General and Experimental Biology SB RAS

6 Sakhyanovoy St., Ulan-Ude 670047, Russia

olennikovdn@mail.ru

\section{Aleksandr O. Zandanov}

Cand. Sci. (Medicine), A/Prof.,

Head of Medical Institute,

Dorzhi Banzarov Buryat State University

36a Oktyabrskaya St., Ulan-Ude 670000, Russia

Abstract. We have analyzed the antiviral properties of a new dry phyto-extract, consisting of the following medicinal plants with a hepatoprotective effect: Hypecoum erectum L., Hedysarum alpinum L., Glycyrrhiza uralensis Fisch., Calendula officinalis L., Scutellaria baicalensis Georgi. It has been revealed in vitro the absence of the cytopathogenic effect of the dry extract and its components. The cell cultures after exposure to the complex plant supplement and its isolated components displayed the absence of cytopathogenic effects. The study of the cytotoxic and antiviral properties of "Gipeliv" extract and its components by means of a microtechnique has show a significant antiviral activity, while the most prominent effects on viral replication was found in Glycyrrhiza uralensis Fisch. and Calendula officinalis L. samples.

Keywords: mixed plant extract, hepatoprotective and antiviral effect.

For citation

Ubeeva E. A., Nikolaev S. M., Ubeeva I. P. et al. Antiviral Properties of the Mixed Plant Extract. Bulletin of Buryat State University. Medicine and Pharmacy. 2021; 2: 3-8 (In Russ.).

The article was submitted 29.10.2021; approved after reviewing 25.11.2021; accepted for publication 22.12.2021. 